\title{
Correction to: Lobbying the lobbyists: when and why do policymakers seek to influence advocacy groups in global governance?
}

\author{
${\text { Kirsten } \text { Lucas }^{1} \text { (D) } \text { Marcel Hanegraaff }}^{2}$. Iskander De Bruycker ${ }^{1}$
}

Published online: 27 August 2019

(c) Springer Nature Limited 2019

\begin{abstract}
Advocacy is typically conceived of as an activity where advocacy groups seek and policymakers grant influence. In this paper, we turn the classic approach to advocacy upside down and ask under what conditions policymakers seek to exert influence on the positions adopted by opposing or allied advocacy groups. Two strategies that policymakers can use in their interactions with advocacy groups are proposed: amplification and persuasion. We build on resource exchange theory and the concept of political opportunity structures to explain which strategy a policymaker uses. The analysis relies on a unique database, which draws from 297 interviews with policymakers from 107 different countries at global climate change and trade conferences. Our results demonstrate that, overall, policymakers seek out advocacy groups more when they are faced with increased levels of political pressures. Namely, elected politicians are more prone to seek out opposing societal interests than non-elected policymakers. Moreover, policymakers from democratically accountable countries, who work on salient issues, are more inclined to mobilize their advocacy group allies.
\end{abstract}

Keywords Transnational advocacy $\cdot$ Policymakers · Advocacy groups · International diplomatic conferences

\section{Correction to: Interest Groups \& Advocacy (2019) 8:208-232 https://doi.org/10.1057/s41309-019-00050-3}

This article was erroneously published in Volume 8, Issue 2 (2019) https://link.sprin ger.com/article/10.1057\%2Fs41309-019-00050-3.

The original article can be found online at https://doi.org/10.1057/s41309-019-00050-3.

Kirsten Lucas

kirsten.lucas@outlook.com

1 University of Antwerp, Sint-Jacobstraat 2, 2000 Antwerp, Belgium

2 University of Amsterdam, Nieuwe Achtergracht 166, 1001 NB Amsterdam, The Netherlands 
The article is now included in the special issue "Advocacy Group Effects in Global Governance: Populations, Strategies, and Political Opportunity Structures" Volume 8, Issue 3 (2019).

\section{Introduction}

'Sometimes NGOs are able to say what we (...) are unable to say' ${ }^{1}$ (policymaker active at UN climate conferences)

Advocacy is typically conceived of as an activity through which advocacy groups seek and policymakers grant influence. This is exemplified by most of the articles in this special issue, in which advocacy groups are studied as actors seeking to impact state decisions (Chalmers, this special issue) or have an actual impact on political decision-making processes (Bob, this special issue). We argue, and empirically demonstrate, that policymakers, in turn, attempt to influence the issue positions and strategies of advocacy organizations. Our argument especially applies to global advocacy and governance. At the international level, the chances of advocacy groups shaping political agreements tend to be relatively limited (e.g. Lucas 2019; Tallberg et al. 2018). Moreover, advocacy groups often invest in other, more elusive activities, such as promoting the visibility of their own organization (Dellmuth and Tallberg 2017; Stroup and Wong 2017), networking with other organizations (Hadden 2015), or monitoring the policymaking process (Hanegraaff et al. 2016). Even when advocacy groups' main purpose is not to impact state decisions, though, they can still serve as excellent liaisons between two or more opposing states (Lowery 2007). For instance, advocacy groups may support domestic policymakers by supplying them with relevant expertise and by promoting the state's political interests to other stakeholders. We thus argue that policymakers are not exclusively on the receiving end of information exchanges with advocacy groups but also reach out to advocacy groups themselves in global governance.

The goal of this article is to conceptually outline and empirically assess the 'influence flow' from policymakers to advocacy groups. Former studies in this tradition have taught us that political institutions can shape the behaviour of advocacy groups (see Bloodgood and Tremblay-Boire 2017; Cooley and Ron 2002; Heylen and Willems 2018; Mahoney 2004; Molenaers et al. 2011; Neumayr et al. 2015; Persson and Edholm 2018; Verschuere and De Corte 2014) and that policymakers pressure these groups into defending policy positions in line with their preferences (Holyoke 2009; Heaney 2006; Heaney and Leifeld 2018; Heaney and Rojas 2015). We build on these findings and seek to explore and explain how policymakers try to shape the policy positions of advocacy groups.

We propose two modes of interaction between policymakers and advocacy groups: amplification and persuasion. On the one hand, policymakers can prompt likeminded advocacy groups (allies) to emphasize and amplify their shared policy

1 Interview conducted at the Conference of Parties in Paris, 4 December 2015.

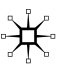


goals when communicating with other relevant stakeholders. On the other hand, policymakers may seek out advocacy groups with opposing views (opponents) in order to persuade them to alternate or soften their position (see Hall and Deardorff 2006). Our objective is to (a) assess the extent to which both amplification and persuasion strategies are employed by policymakers, and (b) explain why some policymakers rely more on amplification while others rely more on persuasion.

To explain this variation, we apply insights derived from both the interest group and (international) non-governmental organizations ((I)NGO) literature, as detailed by Dellmuth and Bloodgood (this special issue). We rely on the concept of 'political opportunity structures', which is commonly used by social movement and (I)NGO scholars to explain why policymakers reach out to interest group allies or opponents (Finnemore and Sikkink 2007; Kitschelt 1986; Kriesi 1995; Risse et al. 2013). From the interest group literature, we use the 'resource exchange theory'. This theory supposes that the transfer of resources, such as political support and information, shapes the interactions among policymakers and advocacy groups (Binderkrantz et al. 2014; Bouwen 2002; Pfeffer and Salancik 1978; Salisbury 1969; Tallberg et al. 2018). Combined, this leads to hypotheses related to the issue context, the institutional environment, and the electoral mandate of the individual policymaker in question (see also Dellmuth and Bloodgood this special issue).

To assess our expectations empirically, we rely on responses from 297 policymakers (diplomats, civil servants, and politicians) from 107 countries during onthe-spot interviews conducted at the Conferences of Parties of the United Nations Framework Convention on Climate Change (UNFCCC) and the Ministerial Conferences of the World Trade Organization (WTO) in 2015 and 2017. We asked policymakers about how often they interacted with advocacy groups, who initiated these interactions, and what policymakers tried to achieve with these interactions. Our results show that saliency increases the propensity of policymakers to motivate allies to amplify their common position and, at the same time, it elicits them to try and persuade opponents; that policymakers from democratically accountable countries are more likely to motivate advocacy groups to more vigorously voice their common position; and that elected officials are more likely to persuade advocacy groups to change their position than diplomats and civil servants active at the international conferences.

\section{Literature review: the other side of the coin}

Over the past decades, many scholars have focussed on the interactions between advocacy groups and policymakers (Bunea and Baumgartner 2014). Most studies have analysed how non-state actors, through their interactions with policymakers, attempt to shape policymaking outcomes (Beyers and Hanegraaff 2017; Gullberg 2008). Although this has led to rich insights into how societal interests seek to impact policy decisions, these studies tend to ignore the overall complexity and reciprocity of the relationship between policymakers and non-state actors. This is what Cowles (2003) labels a 'false dichotomy', whereby advocacy groups are considered as those trying to exercise influence and policymakers as those being influenced. 
Hall and Deardorff (2006) also emphasise the strong demand policymakers experience for interest groups' input, hereby setting the stage for a more nuanced and reciprocal understanding of the relationship between policymakers and lobbyists.

Scholars have started to develop this more nuanced understanding by assessing the role of policy context in lobbying processes (Klüver et al. 2015; Baumgartner et al. 2009; Mahoney 2007). These studies argue that the advocacy activities and policy views of non-state actors are shaped by the overall context in which groups operate, for example the institutional setting (Klüver et al. 2015). Others have moved even further and have argued that the relationship between advocacy organizations and policymakers is strongly steered by the behaviour of policymakers (Ainsworth 1993, 1997; Holyoke 2009, 2011; Matthews 1960). There is a large body of literature dealing with how governments affect the behaviour of advocacy groups through government funding and patronage (Bloodgood and Tremblay-Boire 2017; Cooley and Ron 2002; Heylen and Willems 2018; Mahoney 2004; Molenaers et al. 2011; Neumayr et al. 2015; Persson and Edholm 2018; Verschuere and De Corte 2014). Bloodgood and Tremblay-Boire (2017), for instance, show that government subsidies can have a dampening effect on the advocacy activities of NGOs, and Heylen and Willems (2018) demonstrate how subsidies steer the choice for advocacy venues. There is a considerable amount of research on how policymakers affect the mobilization of advocacy groups by focussing mostly on government funding and financial dependencies.

However, these studies do not analyse the effect of policymakers on the actual issue preferences expressed by advocacy groups. In his article on coalition formation at the US Congress, Holyoke (2009) does take a first step into this direction by showing that advocacy groups require access to policymakers and that the latter use their gate-keeping power to pressure advocacy groups into defending policy positions in line with their preferences. In addition, Heaney and colleagues have shown that the advocacy behaviour of groups is steered by their connections with policymakers (Heaney 2006; Heaney and Leifeld 2018; Heaney and Rojas 2015). These studies are important as they highlight the reciprocal impact policymakers and lobbyists have on each other. What is less clear, however, is how exactly policymakers try to impact the advocacy efforts of lobbyists.

Our argument-and our contribution to the former literature-is that policymakers have, at least, two distinct options to influence lobbyists. On the one hand, policymakers may actively contact allied advocacy groups to serve as 'service bureaus' which provide relevant information and arguments or ask them to rally support for their cause (Crombez 2002; Hall and Deardorff 2006). We label this strategy as 'amplification', because it highlights policymakers' attempts to push lobbyists to openly support their policy positions. On the other hand, a policymaker may contact advocacy groups with opposing views to convince them to change or tone down their position so that it resonates with the policymakers' objectives. We label this strategy 'persuasion', as these actions by policymakers have the intent to persuade lobbyist to change their policy position (Austen-Smith and Wright 1994, 1996; Beyers and Hanegraaff 2017; Corell and Betsill 2001; Gulbrandsen and Andresen 2004; Gullberg 2008; Hansen 1991; Kollman 1997; Marshall 2010). Amplification and persuasion are not geared at changing invisible or latent positions and beliefs 
per se, but rather at changing or activating visible positions which advocacy groups articulate.

Policymakers have good reasons to rely on amplification and persuasion. As for amplification, policymakers may approach allied advocacy groups to build broad coalitions, which are a crucial commodity in any policymaking process. Amplification does require advocacy groups to mobilize, but it also implies that policymakers encourage advocacy groups to voice an outspoken position. Rallying advocacy allies can showcase societal support for the policymaker's goals, thus strengthening the negotiating position of that policymaker. It is of strategic interest to policymakers to foster and consolidate their relationship with non-state actors so that they can mobilize their support base should this be required (Bernhagen and Bräuninger 2005). In addition, policymakers are not always able to publicly express an outspoken position, for example because they are part of a coalition with other countries. With the help of advocacy organizations that can voice such outspoken positions, policy debates might shift into a direction that is in line with the preferences of the policymaker. Moreover, policymakers may seek out supportive interest organizations in order to acquire trustworthy expertise (Gullberg 2008; Potters and van Winden 1992). Policymakers are often generalists and rely on advocacy groups to supply them the (often technical) information which is required during international negotiations (Chalmers 2013a; Klüver 2012). This seems relevant for policymakers at the global level as well. For example, when an international trade regime on export subsidies in agriculture is on the agenda of the Ministerial Conference of the World Trade Organization, a policymaker might consult relevant constituencies and sectors to be aware of the practical implications of the proposals on the table. If policymakers do not have this information at hand, any deal they strike runs the risk of being highly contested in their home country. In addition, policymakers may prioritize their advocacy group allies because these interactions are less costly compared to exchanges with opposing groups. It may be in the interest of the policymaker 'not to debate with his opponents but to stimulate his friends to act' (Bauer et al. 1963: 350). Since policymakers have scarce time and resources, they can reduce costs by approaching advocacy groups that support them rather than those with an opposing view.

The same goes for persuasion, as policymakers also have incentives to approach advocacy groups which do not a priori agree with them. When the main purpose of policymakers is to expand their support base rather than to consolidate it or to acquire technical information, then there is little to gain from contacting likeminded advocacy groups. Considering the context of international conferences, in which large coalitions among state delegations are a prerequisite to materialize change, a large support base is essential. Policymakers might thus reach out to advocacy groups who publicly articulate arguments against their own view in an effort to alter or moderate the advocacy groups' stance. More broadly, policymakers have incentives to entertain contacts with those who oppose them on a particular issue simply because these opponents may become allies on another issue (Gullberg 2008: 2964). Interacting with allies may thus contribute to the development and maintenance of a broad policy network (Gullberg 2008: 2969). 
The rationale behind these strategies is that policymakers seek to expand their tangible support in policy debates. To do so, they pressure interest group allies and opponents to adopt and articulate a position close to their own. This pressure can be coercive, meaning that policymakers threaten to retaliate when interest groups do not comply with their demands. It can also be based on (implicit) promises of gratification, where interest groups are rewarded with access or influence if they conform to the policymaker's request. We presume that these underlying gratification and coercion mechanisms are at play, but do not distinguish between them in our analysis.

In this paper, we aim to explore the extent to which policymakers rely on amplification and persuasion strategies when reaching out to lobbyists. Are they focussing mainly on lobbyists who essentially agree with them to push them to voice their position more outspoken or do they mainly reach out to lobbyist to try and persuade them to take a different position? Importantly, however, we do not only want to explore this variation. We also aim to explain why some policymakers rely more on amplification strategies, while others rely more on persuasion when communicating with lobbyists. Our expectations regarding this latter question are developed in the next section.

\section{Hypotheses: amplification or persuasion}

As this is, to our knowledge, the first study that analyses the different strategies with which policymakers approach interest groups on specific policy issues, our hypotheses are of an explorative nature and build on research conducted in different research fields (e.g. sociology, international relations) and institutional settings (e.g. within the US or EU). As said, we argue that policymakers try to shape the behaviour of non-state actors by adopting either amplification or persuasion strategies. This highlights the fluidity of political opportunity structures as policymakers themselves can shift and shape these structures through which non-state actors navigate on a specific policy dossier (see Green and Auld 2017; Prakash and Potoski 2014). From resource exchange theory, as developed in organisational sociology (Jacobs 1974; Levine and White 1961; Pfeffer and Salancik 1978) and adapted to study advocacy groups (Binderkrantz et al. 2014; Bouwen 2002; Hansen 1991; Salisbury 1969; Steffek 2013; Tallberg et al. 2018; Wright 1996), we learn that interactions among policymakers and advocacy groups are focussed on the transfer of resources such as political support and information. Given that policymakers only have limited time and resources at their disposal (Beyers and Braun 2014; Hall and Deardorff 2006; Jones and Baumgartner 2005), they are presumed to be selective in which advocacy groups they interact with. We explore whether the choice for reaching out to allies (amplification) or opponents (persuasion) is informed by the policy context in which the policymakers operate the institutional context from which they stem, or is the result of an individual policymaker's electoral mandate. We discuss these in turn. 
First, the policy context and, more specifically, the salience of policy issues is consequential for the political pressure policymakers face and the support they seek from societal interests. We define salience as the importance attributed to a policy issue by policymakers (Beyers and Hanegraaff 2017). Issues which are highly salient to policymakers typically attract high levels of advocacy mobilization (Baumgartner and Leech 1998; Raustiala 1997; Skjelsbaek 1971). Higher levels of advocacy mobilization in turn generate pressure and a higher diversity of viewpoints that policymakers need to take into consideration. This also means that advocacy groups are more constrained in shifting policies to their preferred outcomes (Klüver 2011; Mahoney 2007). Salience thus affects the interactions between non-state actors and policymakers and the political opportunity structure of advocacy groups (Dellmuth and Bloodgood this special issue). More precisely, we expect that salience makes policymakers more likely to use both amplification and persuasion. The logic is as follows: policymakers are much more active and consequently experience a relatively higher demand for information and political support on issues that they consider important. Moreover, salient issues attract more advocacy mobilization, which, in turn, leads to an increased supply of information and political support. Therefore, policymakers will more vigorously seek out advocacy groups on salient issues. If policymakers succeed in securing support from opponents and allies, this provides them with the necessary tools to signal the scope of support for their cause and helps them in realizing their preferred policy outcome.

H1 Policymakers working on issues which they perceive as more salient are more prone to use both amplification and persuasion strategies towards advocacy groups.

Second, the political pressures policymakers face and their need for political support vary depending on the institutional context in which they are embedded. One specific factor of this context is the level of democracy of the country a policymaker hails from (Beckfield 2003; Bernauer et al. 2013; Beyers and Hanegraaff 2017; Dalton et al. 2003; Lee 2010; Smith and Wiest 2005; Tallberg et al. 2014, 2018). In a democracy, policymakers are held accountable to the public through free and fair elections, referenda, and other forms of citizen involvement or activism (such as protests, public deliberations, media campaigns, or consultations). This leads policymakers from democratic polities to place relatively greater value on exchanges with opposing interests than policymakers hailing from less democratic countries do. In established democracies, the activities of opposing groups are more consequential for political debates and the political competition is fiercer in comparison with less democratic countries. Based on this reasoning, we expect policymakers hailing from democratic countries to value exchanges with opposing groups more than policymakers from less democratic countries.

Not only opponents, but also allied groups, are expected to be more important for policymakers hailing from democracies. Non-state actor communities in democracies are typically large and are thus an abundant source of technical information and political support (Lohmann 1998). Policymakers in democratic countries cannot exclusively focus on trying to persuade their opponents but 
should invest more in consolidating and mobilizing allied political support. In less democratic countries, advocacy communities are typically less developed and opponents are often silenced through government control. As a result, policymakers from these countries face less competition when securing societal support, i.e. support from the existing (often state-controlled) advocacy group community is obvious and less competitive. Importantly, we do not argue that in democratic states it is easier for advocacy groups to realize policy objectives (Lucas 2019; Risse-Kappen 1995). On the contrary, in this regard Bernauer et al. (2013) even speak of a 'civil society-democracy paradox': a higher number of advocacy groups leads to weaker influence of societal interests. Nonetheless, in democracies, the struggle for political support is more intense and the advocacy group communities more developed. This leads democratic policymakers to approach both allies and opponents relatively more often than policymakers coming from less democratic countries.

H2 Policymakers hailing from democratic countries are more prone to use both amplification and persuasion compared to policymakers hailing from less democratic countries.

Third, whether policymakers rely on amplification and persuasion strategies is contingent not only on the policy and institutional context, but also on the political mandate of the policymaker. Policymakers' strategic choices are informed by the relationship with their constituencies and, more specifically, by whether they are subject to political pressure or electoral retribution from their constituencies. Elected politicians depend on public support and are particularly likely to be susceptible to pressure from opposing advocacy groups. Politicians may seek out these advocacy groups because they need to be responsive to political pressures and public demands. Otherwise, they can be penalized through democratic control mechanisms (such as elections or protest) (Heaney 2006; Kollman 1998; Schattschneider 1960).

A wide variety of policymakers are active at international conferences, many of whom are not elected, such as professional diplomats (representing the ministries of foreign affairs of the member-states of these international organizations) or civil servants (working for other ministries, agencies, and government bodies). These policymakers do not face electoral retribution if they fail to engage with opposing societal views, nor do they require the amount of political information or support elected politicians need. We therefore expect that the electoral mandate of a policymaker not only affects how she interacts with non-state actors (e.g. Beyers and Kerremans 2004; Lohmann 1998) but also which type of advocacy groups she decides to approach. Namely, we expect that elected politicians are more likely to build a broad support base by trying to persuade advocacy groups with opposing views. Policymakers who face no electoral retribution and fewer political pressures, on the other hand, are more likely to approach allies to stimulate them to voice an outspoken and supportive position. This leads to our third hypothesis: 
H3 Elected politicians are more prone to persuade advocacy groups of their own position compared to non-elected policymakers.

\section{Research design}

The subsequent analyses rely on a novel dataset collected during on-the-spot interviews with policymakers active in the fields of trade and climate change. In 2015, the 21st Conference of Parties and 10th Ministerial Conference were organized, and in 2017, the 23rd Conference of Parties and the 11th Ministerial Conference took place. A team of researchers interviewed government-attendees regarding their interactions with non-state actors at these four conferences. An on-the-spot fieldwork coordinator pointed interviewers to respondents and ensured that all the physical areas of the conference space were covered. All respondents that initially refused to participate in our research, mostly due to time concerns, were invited to fill in the survey afterwards. We are confident that our approach enabled us to reduce bias in the type of respondents, with regard to both the type of policymaker (diplomat, civil servant, politician) and the country they were representing (see "Annex I" for a more detailed discussion). For example, government officials representing the small island-state of Sao Tomé and Principe and those representing the USA are included in our dataset. After all four conferences, we also conducted a web survey ${ }^{2}$ among participants that we had not managed to speak to. Combining the on-the-spot interviews with the web survey data led to a total response rate of more than $35 \% ; 297$ policymakers hailing from 107 countries are included in the analyses for this article.

The interviews were partly centred on 13 policy issues for the UNFCCC and 17 for the WTO. ${ }^{3}$ These issues were identified through qualitative interviews (conducted prior to the fieldwork) with policymakers and non-state actors, the provisional agendas of the Conferences of Parties and Ministerial Conferences, draft agreements, position papers, and media reports. An example of an issue discussed at the UNFCCC is whether the global temperature rise should be limited to 2 degrees Celsius above pre-industrial levels, 1.5 degrees, or lower than 1.5 degrees. The first half of the interviews centred around one specific issue that was randomly selected from issues that the respondents had marked as 'important' or 'very important'. The second half of the interviews dealt with climate change and trade policy in general, and the questions in this part were not issue specific.

Next, we present the operationalization of the variables (see Table 1 for an overview). For the dependent variable, we relied on the following survey question: 'In your contacts with non-state stakeholders, you may pursue some goals that might help you during the negotiations. How often do you...? (1) Try to convince non-state stakeholders of your own position and (2) Encourage them to voice an outspoken

\footnotetext{
2 The questions in this survey were also identical to the questions in the interviews. Only small linguistic changes were made. For example, during the interviews, we asked policymakers: "At this Conference of Parties (COP)...". In the survey, this was changed to "At COP21...".

3 See "Annex II" for more information on the issues.
} 


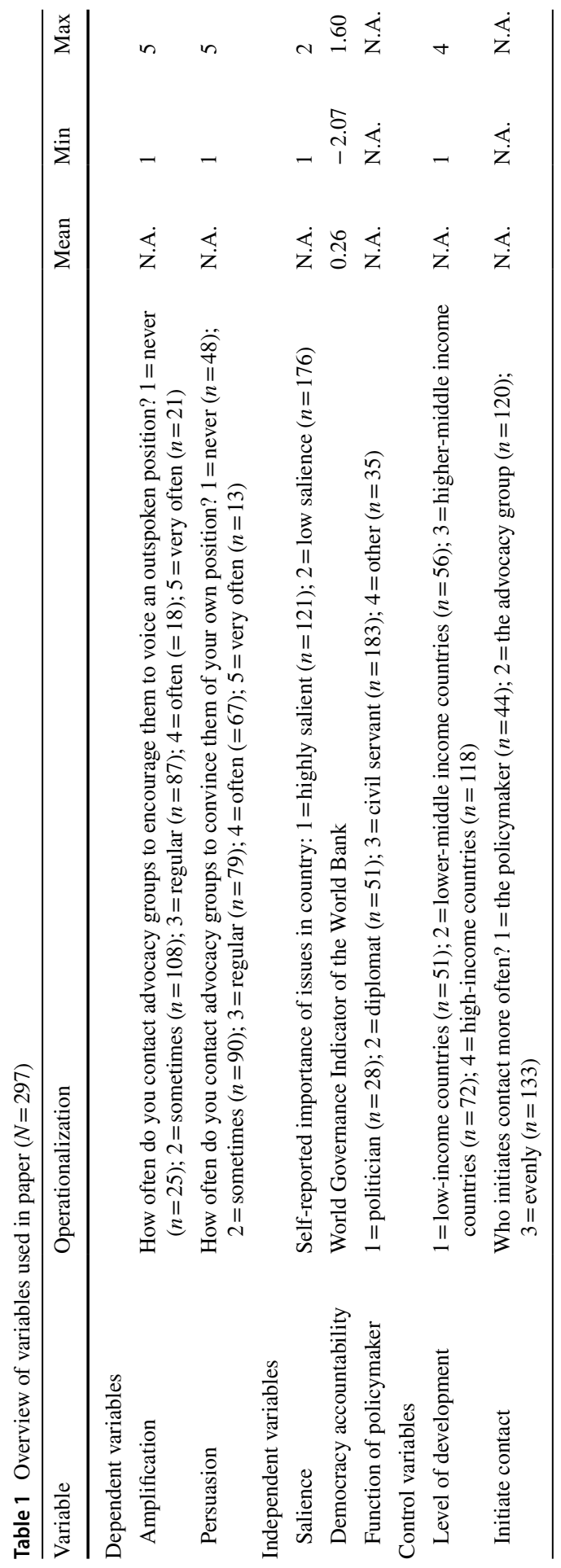

2. 
position'. The answer categories range from 1 ('never') to 5 ('very often') ${ }^{4}$, and the first question refers to persuasion, while the second describes amplification.

In order to test Hypothesis 1 on salience, we relied on responses to a survey question about the importance of the specific issue compared to other issues on the policy agenda of the country (ranging from $0=$ 'less important', $1=$ 'as important' to 2 = 'more important'). To assess Hypothesis 2 on the level of democracy, the variable of democratic accountability was based on the Voice and Accountability indicator of the World Bank. This indicator measures perceptions of the extent to which citizens are able to participate in selecting their government, as well as freedom of expression, freedom of association, and a free media. ${ }^{5}$ Finally, in order to test Hypothesis 3, we relied on a survey question about the function of the respondent. Here, the answer categories were (1) diplomat, (2) civil servant, (3) elected official/ politician, and (4) other.

Several control variables were added to the analyses. We first controlled for the level of development, based on the World Bank classification system, which makes a distinction between four categories: low-income countries, lower-middle-income countries, higher-middle-income countries, and high-income countries. The categorization is a combined construction of gross national income per capita, the human asset index, and the economic vulnerability index. It could be that in less developed countries, policymakers depend more on the input of advocacy groups. This would mean that, in these countries, activating both advocacy group allies and opponents would be more common. The second control variable relates to the interactions policymakers have with non-state actors and is based on the following question: 'With regard to the contacts you have with non-state stakeholders, is it mostly you who seeks and initiates contact with them or they who initiate contact with you? Or would you say that the contact is initiated rather evenly?'. One could, for instance, imagine that policymakers who do not reach out to advocacy groups are less likely to either use amplification or persuasion, simply because they do not consider advocacy groups to be important players.

\section{Results}

\section{Descriptive analysis}

How common is it for policymakers to approach advocacy groups at international conferences? Figure 1 shows that both amplification and persuasion are quite common tactics for policymakers. More than half of the respondents indicated they use one or both of them 'regularly', 'often', or 'very often'. Clearly, our presumption that policymakers target advocacy groups is not far-fetched. If

\footnotetext{
4 When respondents were unsure which category to pick, researchers explained that 'regularly' refers to multiple times a year, 'often' to once every month and 'very often' to more than once a month.

5 https://datacatalog.worldbank.org/dataset/worldwide-governance-indicators (accessed 21 August 2018).
} 


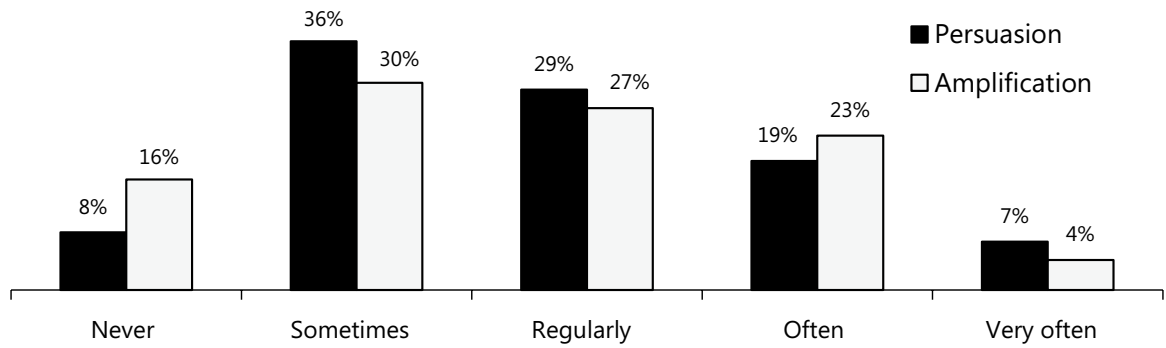

Fig. 1 Frequency using amplification and persuasion $(N=297)$

Table 2 Distribution information exchanges between advocacy groups and policymakers, by content and type, in \% $(N=297)$

\begin{tabular}{llrrlll}
\hline & \multicolumn{3}{l}{ Amplification } & & \\
\cline { 2 - 6 } & Never & Sometimes & Regularly & Often & Very often \\
\hline Persuasion & & & & & \\
Never & 4.7 & 2.7 & 0.7 & 0 & 0.3 \\
Sometimes & 6.4 & 15.8 & 7.1 & 5.4 & 1.7 \\
Regularly & 3 & 8.1 & 11.8 & 6.1 & 0.3 \\
Often & 1 & 2.4 & 5.4 & 9.1 & 1 \\
Very often & 1 & 1.3 & 1.7 & 2 & 1 \\
\hline
\end{tabular}

we compare both strategies, we see that there is not much difference in how often these are applied. On average, persuasion is slightly more common than amplification (mean persuasion is 2.80; amplification is 2.69). Overall, these results differ from previous studies on advocacy groups, which show that mobilizing allies is much more common than advocating opponents (see for instance Beyers and Hanegraaff 2017). One reason for this difference could be that in our study we explicitly asked why policymakers interacted with allied or opposing advocacy groups. Did they do so to encourage advocacy groups to voice an outspoken position that is similar to that of the policymaker? Or did they want to persuade them? In previous studies on advocacy groups (e.g. Beyers and Hanegraaff 2017; Chalmers 2013b; Gullberg 2008), these motivations for interaction were not questioned. Another possible explanation is that policymakers have more leverage (such as government donations, policy access, and influence) to impact advocacy group behaviour than vice versa and therefore have more plausible prospects when approaching both allied and opposing advocacy groups.

One question is how amplification and persuasion are related. In other words, are some policymakers more inclined to reach out to advocacy groups-either allied or opposing ones-or is it rather that some focus almost exclusively on their allies, while others focus mostly on their opponents? Table 2 shows that there is indeed a significant correlation between approaching allies and opponents (Spearman's rho $=0.41 ; P=0.00$ ); although the correlation is relatively weak. The results indicate that policymakers who try to persuade opponents show, on average, a higher propensity to also adopt the strategy of amplification. At the same time, there is 
Table 3 Why do policymakers use amplification or persuasion?

\begin{tabular}{|c|c|c|c|c|}
\hline & \multicolumn{2}{|c|}{$\begin{array}{l}\text { Model I } \\
\text { Amplification }\end{array}$} & \multicolumn{2}{|l|}{$\begin{array}{l}\text { Model II } \\
\text { Persuasion }\end{array}$} \\
\hline & Coefficient & S.E. & Coefficient & S.E. \\
\hline \multicolumn{5}{|l|}{ Explanatory variables } \\
\hline Salience of issue & $0.323 * *$ & $(0.131)$ & $0.265 * *$ & $(0.126)$ \\
\hline Democratic accountability & $0.261 * *$ & $(0.109)$ & 0.066 & $(0.106)$ \\
\hline \multicolumn{5}{|l|}{ Function } \\
\hline Politician (ref.) & Ref. & & Ref. & \\
\hline Diplomat & -0.412 & $(0.254)$ & $-0.566^{* *}$ & $(0.245)$ \\
\hline Civil servant & -0.214 & $(0.222)$ & $-0.492 * *$ & $(0.215)$ \\
\hline Other & 0.093 & $(0.271)$ & -0.242 & $(0.262)$ \\
\hline \multicolumn{5}{|l|}{ Control variables } \\
\hline \multicolumn{5}{|l|}{ Level of development } \\
\hline High income (ref.) & Ref. & & Ref. & \\
\hline Medium high income & $0.483 * *$ & $(0.204)$ & 0.334 & $(0.201)$ \\
\hline Medium low income & $0.562 * *$ & $(0.265)$ & 0.293 & $(0.258)$ \\
\hline Low income & $1.017 * * *$ & $(0.271)$ & $0.450 *$ & $(0.265)$ \\
\hline \multicolumn{5}{|l|}{ Initiate contact } \\
\hline Evenly (ref.) & Ref. & & Ref. & \\
\hline Advocacy group & $-0.382 * *$ & $(0.136)$ & -0.111 & $(0.132)$ \\
\hline Policymaker & 0.210 & $(0.191)$ & -0.274 & $(0.184)$ \\
\hline \multicolumn{5}{|l|}{ Diagnostics } \\
\hline Intercept & $2.408 * * *$ & $(0.258)$ & $2.892 * * *$ & $(0.250)$ \\
\hline Country-level intercept & 0.000 & $(0.000)$ & 0.016 & $(0.058)$ \\
\hline Level 1 residual & 1.124 & $(0.092)$ & 1.036 & $(0.101)$ \\
\hline Log-likelihood & -440.263 & & -431.835 & \\
\hline$N$ & 298 & & 299 & \\
\hline
\end{tabular}

The model is a mixed-effects linear regression which estimates a random intercept for each 107 countries. Coefficients, standard errors (in parentheses), and significance are presented, whereby: ${ }^{*} P<0.1$; $* * P<0.05 ; * * * P<0.01$

variation as some policymakers are more focussed on their allies (persuasion) and some on their opponents (amplification). As can be seen in Table 2, more than $40 \%$ of the policymakers approach allies and opponents equally often, which means that around $60 \%$ of the policy delegates focus on either persuasion or amplification.

\section{Multivariate analysis}

In our multivariate analyses, with amplification and persuasion as dependent variables, we aim to explain the variation presented before. Since policymakers are nested in countries, we run a mixed-effects ordinary least squares regression with 

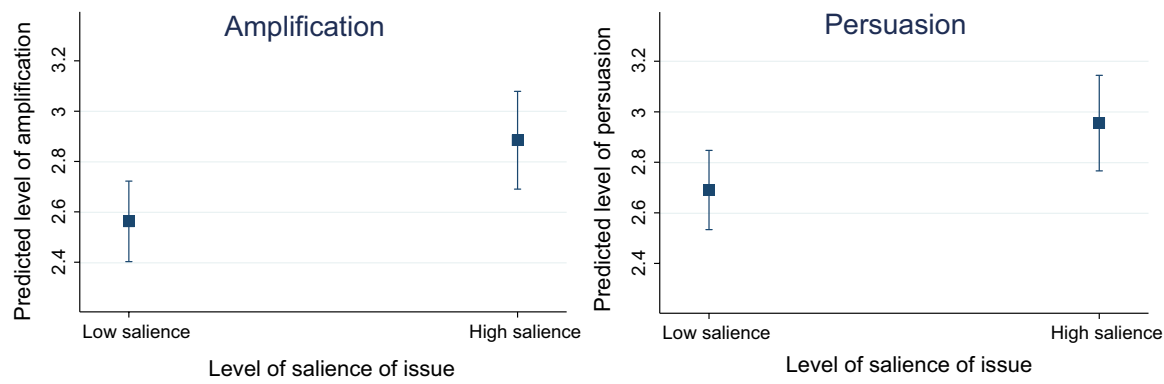

Fig. 2 Predicted probability plots for amplification (left) and persuasion (right), by varying levels of salience. Notes: See Table 3, based on Model 1 (left) and Model 2 (right)

random intercepts for the countries from which policymakers stem $(N=107$ countries). ${ }^{6}$ Table 3 summarizes the results.

What do the results tell us? First, concerning the policy context, Table 3 and Fig. 2 show that on highly salient issues, policymakers more often seek contact with advocacy groups to encourage them to voice their opinion more loudly (amplification) and to convince them of their own position (persuasion). The results indicate that the effect of salience is slightly stronger for the amplification strategy (from 2.58 to 2.90 ) than for persuasion (from 2.70 to 2.96 ). On salient issues, policymakers are in higher demand for political support and expertise to help them secure the preferred policy outcome. When policymakers are able to show that their policy outcome is broadly supported, they have a higher chance of moving the decision-making process in their preferred direction. However, especially on highly salient issues, which tend to attract many different advocacy organizations, policymakers need to selectively prioritize their targets. On these issues, securing support and information subsidies from allies is less risky than trying to persuade opponents. Hence, policymakers reach out to opponents somewhat less often than to their allies. Overall, Hypothesis 1 is thus confirmed.

Second, we focus on the institutional context. Here, we see that, as expected, policymakers hailing from democracies tend to rely relatively more on the amplification strategy, asking advocacy allies to voice their common position more vigorously. In contrast, we see no statistical difference between the level of democratic accountability and the extent to which policymakers attempt to persuade advocacy groups to take a different position (see also Fig. 3 for a visual depiction of the results). This only partially confirms Hypothesis 2 . The difference could be explained by the fact that advocacy group communities in democratic states are typically large and the struggle for their support is more competitive (Lohmann 1998). It could be said, then, that policymakers in democratic countries reach out

\footnotetext{
${ }^{6}$ As robustness checks (see "Annex III"), we first ran ordered logistic regression to see whether this changed the results, and it did not. Second, we performed seemingly unrelated regression analyses to check whether the error terms in the regression equations for amplification and persuasion are correlated. This did not change the results either.
} 

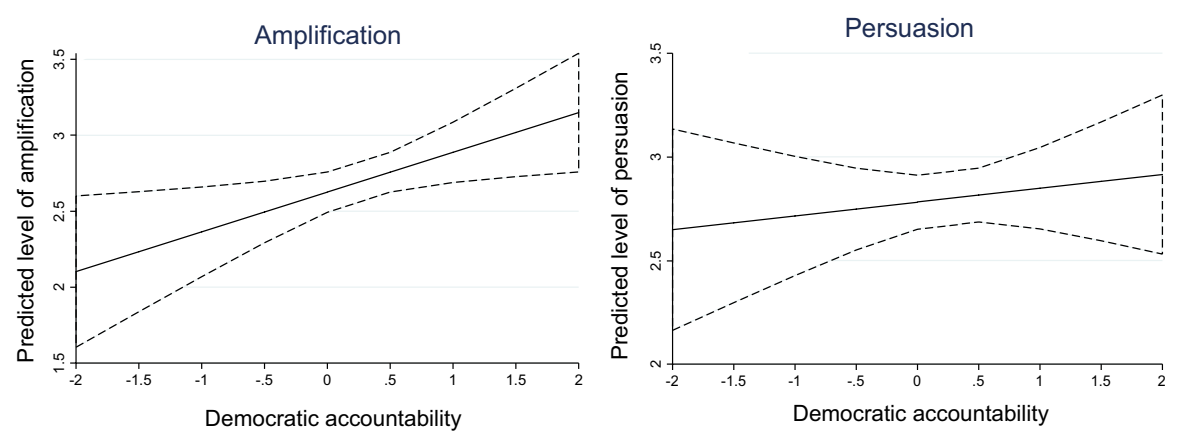

Fig. 3 Predicted probability plots for amplification (left) and persuasion (right), by varying levels of democratic accountability. Notes: See Table 3, based on model 1 (left) and model 2 (right)
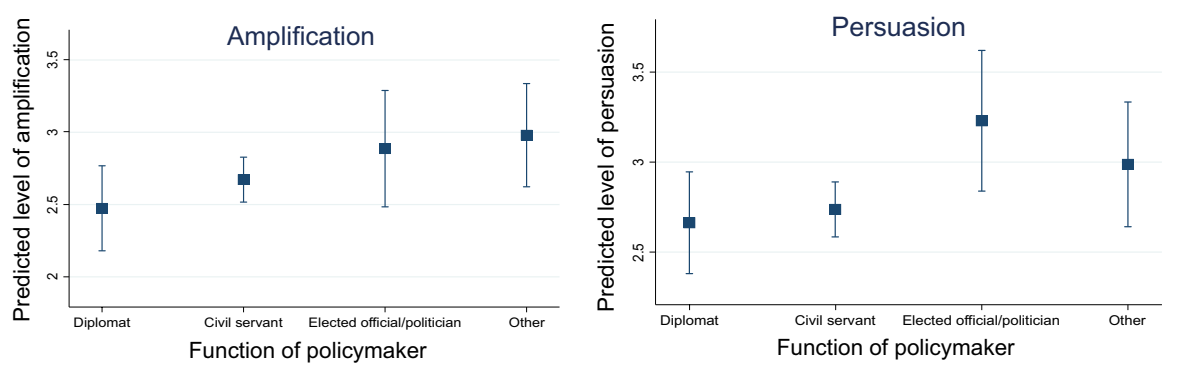

Fig. 4 Predicted probability plots for amplification (left) and persuasion (right), by different types of policymakers. Notes: See Table 3, based on model 1 (left) and model 2 (right)

to allies more often than to opponents in comparison with policymakers in nondemocratic states because the former is a less risky strategy than the latter. In order to extensively analyse the role of the institutional context on persuasion, more detailed country-level variation seems necessary. For example, the type of political system - such as majoritarian versus consensus democracies-could be used in future research to flesh out why (or why not) opponents are more frequently approached by policymakers across countries.

Third, with regard to the political mandate of the policymaker, we see that elected politicians are significantly more prone to trying to persuade advocacy groups than other types of policymakers are (see Fig. 4 for a visual depiction of the results). Hypothesis 3 is thus confirmed. Elected politicians are more inclined to build a broad and encompassing support base by trying to persuade interest organizations with opposing views compared to non-elected civil servants and diplomats. Moreover, elected politicians seem much more sensitive to the political environment as part of their political mandate. Since these politicians are subject to electoral retribution and are more sensitive to legitimacy loss, they are more likely to approach advocacy groups with opposing views to attempt to persuade them of their own 
opinion, hoping that these groups will in turn halt or tone down their criticism in public debates. Policymakers who are not concerned about re-election, on the other hand, are not significantly more likely to use the strategy of amplification. Political opposition is apparently less consequential to them as it will usually not immediately lead to a loss in power or legitimacy.

\section{Conclusion}

This article started from the premise that policymakers are dependent on advocacy groups for political support and expertise. Policymakers were presumed to actively seek out and 'lobby the lobbyists' to secure political support and gather relevant expertise. We identified two strategies: (1) amplification, which involves approaching allied advocacy groups, and (2) persuasion, which includes exchanges with advocacy group opponents. In line with the objective of the special issue, we attempted to explain variation in both tactics by examining the information needs of policymakers and advocacy groups, and how this is mediated by the institutional and policy context (see Dellmuth and Bloodgood this special issue).

The results demonstrate that, overall, policymakers seek out advocacy groups more when they are faced with increased levels of political pressures. While recent studies have conceptualized the relationship between advocacy groups and policymakers in global policymaking as an exchange of expertise (Dellmuth and Tallberg 2017), our findings point at the importance of advocacy group opposition and support in these interactions. Namely, elected politicians are more prone to seek out opposing societal interests to try to persuade them to adjust or tone down their position. Moreover, in line with the broader expectation of this special issue, we found that the exchanges between advocacy groups and policymakers are critically mediated by the institutional and policy context in which policymakers operate. Salience affects both the mobilization of allies and opponents by policymakers, and policymakers from democratically accountable countries are more inclined to use amplification.

Our study integrates a new perspective into the literature on advocacy groups as we studied the perceptions of policymakers rather than the perspective of advocacy groups in lobby exchanges. Interestingly, we identified a genuine interest among policymakers in their advocacy opponents; policymakers at international conferences are slightly more likely to try and persuade their opponents rather than mobilize their allies. This finding sheds new light on the interest group literature which has systematically found that advocacy groups prefer to engage in cooperative exchanges with likeminded policymakers rather than persuade opposing policymakers (e.g. Beyers and Hanegraaff 2017; Chalmers 2011; Crombez 2002; Gullberg 2008; Hall 2006). Our study shows that this does not necessarily hold true for advocacy interactions initiated by policymakers, and this area clearly warrants additional research, for instance by combining the preferences of both state officials and advocacy groups in one research design.

Another key contribution is that we empirically show that policymakers, by choosing either amplification or persuasion tactics, affect the behaviour and 
opportunities of advocacy groups. At the same time, policymakers are at the receiving end of these exchanges. This is an important addition to the (I)NGO and interest groups literature as it highlights the fluidity of political opportunity structures and shows how policymaking is set by non-state and state actors together (see Green and Auld 2017; Prakash and Potoski 2014). We believe this provides multiple avenues for future research, for instance, on how often policymakers successfully change the position of advocacy groups.

There is thus much room for future research to further substantiate our theoretical ideas and research findings. First, while our study is the result of a large-scale collaborative research project and draws from an extensive and novel database, it is confined to policymakers present at international conferences. Our findings can therefore not be readily generalized to policymakers that did not participate in these conferences (e.g. the majority of local politicians and national parliamentarians). However, since international conferences can be considered as a 'least likely case' for policymakers to value and seek political support, we expect our findings to travel well to other policy contexts and political arenas. Most prominently, our findings related to the national context do probably not only apply to policymakers and advocacy organizations from these countries that work in a global context. On the contrary, it seems reasonable that the country differences we observed are applicable to advocacy groups and policymakers working exclusively at the national level as well. However, the importance of salience might be an exception though. As transnational issues tend to be less salient than domestic issues, policymakers reach out to advocacy groups even more at the national level than at the international level. Yet, this should not necessarily affect the way in which they approach advocacy groups, as salience seems to enhance both amplification and persuasion according to our findings. At this point, we can only speculate about potential similarities and differences, due to the type of data we have collected. Future studies could build on our theoretical rationale and assess the external validity of our findings beyond the case of transnational policymaking.

Second, as indicated, this study has only scratched the surface of what we believe is a crucial dimension of state-advocacy group relations. We therefore hope future studies will more explicitly consider the active role of policymakers in their exchanges with advocacy groups. One possibility is to use a more qualitative approach that allows for unravelling the mechanisms underlying amplification and persuasion strategies. Our explorative in-depth interviews indicate that, especially in developed countries, ministries organize meetings with advocacy groups in preparation of the global conferences. As the Dutch chief negotiator at the UN climate conferences explained: we were very active in approaching actors (...) not only companies, but also provinces and cities. We saw an ambition there and we did not see that [ambition] being reflected in these [climate] negotiations. (...) So we went to these actors to talk [and ask]: 'Do you have ideas to improve it? "7 This also touches a point that requires further study, namely the role that is attributed to advocacy groups within the political system. A possible explanation why amplification is used

\footnotetext{
7 Interview conducted at the UNFCCC preparatory meeting in Bonn, June 2015.
} 
more often in democratically accountable countries might be that in these countries, advocacy groups are seen as serious actors, while in other, less democratically accountable countries, this might be different. As one civil servant explained: We don't talk to them, because first of all they don't come to us and if they do come to us they do not want to talk about the reality, their position is very ideological. There is little space for dialogue. (...) At the political level, the politicians know that the NGOs will do them no harm, so they try to make policies based on the current situation. ${ }^{8}$ Such anecdotes highlight the need for more research to explore the ways in which policymakers reach out to lobbyist as well as the impact this has on the work of lobbyist and, eventually, the policy process.

Third, this article provided three general hypotheses to explain the use of amplification or persuasion strategies by policymakers. However, many other explanatory factors, or more complex relations, could exist. For instance, are there differences among policymaker's ideological positions (e.g. left-right), or politicians in a position of power or not? These questions fall beyond the scope of this paper. More research into this area is thus very welcome in order to expand our understanding of the interactions between policymakers and non-state actors and the role and influence of advocacy groups in global governance.

Acknowledgements Iskander De Bruycker gratefully acknowledges support of the Research Foundation Flanders - FWO (Post doc Grant No. 12N1417N). The authors thank Lisa Dellmuth, Elizabeth Bloodgood and the anonymous reviewers for their constructive comments which helped improve the article considerably. An earlier version of the article was presented at the special issue's workshop in Stockholm (June 2018). We are grateful to the participants of this workshop for their helpful feedback.

\section{Compliance with ethical standards}

Conflict of interest On behalf of all authors, the corresponding author states that there is no conflict of interest.

\section{Annex I-Methodology}

With a team of researchers, we randomly conducted interviews with policymakers at the COPs and MCs. The respondents were chosen by the researcher in charge ('pointer') to make sure interviewers would not (unknowingly) have a bias in their selection of respondents (e.g. convenience sampling). Moreover, the researcher in charge made sure all physical areas at the conference location were targeted in order to increase the chance of getting a random and representative sample of the participants at the conferences. The fact that our sample includes policymakers from over 100 hundred countries, including both key players (Russia, China, the United States) and policymakers from smaller countries (Samoa, the Netherlands), makes us confident the sample is a good representation of the broader population.

${ }^{8}$ Interview conducted at the UNFCCC preparatory meeting in Bonn, June 2015.

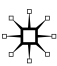


In total, we conducted 181 interviews at the climate conferences and 93 interviews at the trade conferences. The response rate is almost $50 \%$, based on our notes of the interviews each of our team members did and the rejections we received. There is no reason to believe that policymakers who refused to be interviewed are fundamentally different from the ones who participated. In addition, we noticed that most refusals were not because policymakers did not want to participate in our research, but because they had limited time during the negotiations. Therefore, we have no indications that the sample has affected the results. Moreover, one needs to bear in mind that the rejections could be from all types of actors present at the international conferences: policymakers, representatives of international organizations and representatives of advocacy groups. We were unable to specify response rates per group of actors, since we simply approached people on the conference sites and often did not know what type of actor we invited for an interview. Also, sometimes advocates were invited (unintentionally) two or three times by different interviewers or they refused the first invitation but then agreed when invited again. However, because we monitored which countries and types of policymakers we had already covered during the fieldwork, we were able to improve the representativeness of our sample considerably. For example, during the climate conference in Paris one of our researchers spent considerable time getting Chinese and Russian policymakers to participate.

The interviews were combined with data that we collected through a web survey immediately after the conferences. Between January and April 2016, we sent out surveys to all country delegations that our team did not manage to interview while we were in Paris and Nairobi. To policymakers active at the climate conference in Bonn, surveys were sent out between December 2017 and January 2018. This means that respondents who were too busy during the negotiations were given another opportunity to participate in our research. The respondents were selected on the basis of the provisional list of participants for the UNFCCC; this list includes the non-state actors, international organizations, and states that received accreditation and their representatives. In addition, we sent the questionnaire to all policymakers from whom we received a business card during our time in Paris and Bonn, but whom we did not manage to interview. Due to tensions between China and Chinese Taipei, the WTO secretariat is not allowed to distribute a list of participating countries. Instead, we provided the secretariat with a list of countries that were still missing in the database and received the contact details of the focal points of these delegations. In doing this, we made sure that there was an equal distribution among the different continents and the size of countries. (We selected both small and bigger countries.) Moreover, we selected countries that represent the different coalitions within the WTO, such as the ACP Group or the Cotton-4. We also sent the survey to government representatives of whom we had received a business card during the conferences in Nairobi and Buenos Aires.

The questionnaires were sent out quickly after the conferences took place. In this way, we tried to reduce memory loss among the respondents; what happened during the conference was still fresh in their mind. Of all the invitations for the survey that we sent $(N=1590), 310$ respondents (partially) completed the survey. That 
Table 4 Issues discussed at the UNFCCC COPs

\begin{tabular}{ll}
\hline Issue & Year \\
\hline Climate finance: who should contribute? & 2015 \\
Degrees-goal & 2015 \\
NDCs: Annex or COP decision? & 2015 \\
MRV: strength of compliance (developing) & 2015 \\
MRV: strength of compliance (developed) & 2015 \\
NDCs: commitment period and assessment & 2015 \\
Loss and damage: finance mechanism & 2015 and 2017 \\
Loss and damage: funding & 2015 and 2017 \\
NDCs: guidance & 2017 \\
Adaptation Fund & 2017 \\
Transparency Framework & 2017 \\
Gender Action Plan & 2017 \\
Adaptation Communication & 2017 \\
\hline
\end{tabular}

is a response rate of $19.5 \%$. This rate was achieved by sending out two electronic reminders, after 2 weeks and 4 weeks. One has to bear in mind that the respondents come from all over the world and many governments active at these conferences lack a website that is up to date, which meant that we could not send our invitations to the right persons. Moreover, some of the invitations could not be delivered or were bounced, for example because the email addresses were not working.

\section{Annex II-Issues}

The interviews and surveys used for this paper were partly policy-centred. The policy issues were selected by combining qualitative interviews with the provisional agreements, the provisional agendas, news articles and position papers of interest organizations. In total, thirteen policy issues for the UNFCCC were identified and seventeen for the WTO. Some issues were on the negotiating table in both 2015 and in 2017, while others were only relevant during one of the two interview rounds. In Tables 4 and 5, we present the issues that were discussed at these four conferences.

On each of these issues, several policy positions and the status quo were identified. For example, on the future of the Doha Development Agenda, we asked respondents whether they were advocating (1) full implementation of the original DDA mandate, or whether they were in favour of (2) continue working on DDA while exploring different negotiating approaches, or whether they wanted to (3) end DDA and draft a new work programme. On this issue, the status quo is full implementation of the mandate, since this was reaffirmed in the Nairobi Ministerial Declaration. 
Table 5 Issues discussed at the WTO MCs

\begin{tabular}{ll}
\hline Issue & Year \\
\hline GATS negotiations & 2015 \\
TiSA negotiations & 2015 \\
Export subsidies in agriculture & 2015 \\
Export subsidies in agriculture: marketing and & 2015 \\
$\quad$ internal transportation subsidies & \\
Agriculture: pillars & 2015 \\
Cotton & 2015 \\
Non-Agricultural Market Access (NAMA) & 2015 \\
Special Safeguard Mechanism on Agriculture & 2015 and 2017 \\
Future of the Doha Development Agenda (DDA) & 2015 and 2017 \\
Public stockholding in agriculture & 2017 \\
Public stockholding: conditions & 2017 \\
Fisheries & 2017 \\
E-commerce & 2017 \\
E-commerce: who should negotiate & 2017 \\
Investment Facilitation & 2017 \\
Investment Facilitation: who should negotiate & 2017 \\
Trade Facilitation Agreement on Services & 2017 \\
\hline
\end{tabular}

\section{Annex III-Robustness checks}

Robustness check I. Ordered logistic regression models with random intercept for all 107 countries included

\begin{tabular}{|c|c|c|c|c|}
\hline & \multicolumn{2}{|c|}{$\begin{array}{l}\text { Model I } \\
\text { Amplification }\end{array}$} & \multicolumn{2}{|l|}{$\frac{\text { Model II }}{\text { Persuasion }}$} \\
\hline & Coefficient & S.E. & Coefficient & S.E. \\
\hline \multicolumn{5}{|l|}{ Explanatory variables } \\
\hline Salience of issue & $0.571^{* *}$ & $(0.223)$ & $0.477 * *$ & $(0.229)$ \\
\hline Democratic accountability & $0.463 * *$ & $(0.189)$ & 0.155 & $(0.198)$ \\
\hline \multicolumn{5}{|l|}{ Function } \\
\hline Politician (ref.) & Ref. & & Ref. & \\
\hline Diplomat & $-0.773 *$ & $(0.436)$ & $-1.046^{* *}$ & $(0.442)$ \\
\hline Civil servant & -0.406 & $(0.375)$ & $-0.949 * *$ & $(0.396)$ \\
\hline Other & 0.110 & $(0.462)$ & -0.511 & $(0.476)$ \\
\hline \multicolumn{5}{|l|}{ Control variables } \\
\hline \multicolumn{5}{|l|}{ Level of development } \\
\hline High income (ref.) & Ref. & & Ref. & \\
\hline Medium high income & $0.872^{* *}$ & $(0.354)$ & 0.572 & $(0.109)$ \\
\hline Medium low income & $1.023^{* *}$ & $(0.452)$ & 0.494 & $(0.308)$ \\
\hline Low income & $1.812 * * *$ & $(0.482)$ & 0.786 & $(0.116)$ \\
\hline Initiate contact & & & & \\
\hline
\end{tabular}




\begin{tabular}{|c|c|c|c|c|}
\hline & \multirow{2}{*}{\multicolumn{2}{|c|}{$\frac{\text { Model I }}{\text { Amplification }}$}} & \multirow{2}{*}{\multicolumn{2}{|c|}{$\begin{array}{l}\text { Model II } \\
\text { Persuasion }\end{array}$}} \\
\hline & & & & \\
\hline & Coefficient & S.E. & Coefficient & S.E. \\
\hline Evenly (ref.) & Ref. & & Ref. & \\
\hline Advocacy group & $-0.641 * * *$ & $(0.236)$ & -0.241 & $(0.237)$ \\
\hline Policymaker & 0.353 & $(0.324)$ & 0.483 & $(0.341)$ \\
\hline \multicolumn{5}{|l|}{ Diagnostics } \\
\hline Intercept 1 & $-1.289 * * *$ & $(0.454)$ & $-2.749 * * *$ & $(0.504)$ \\
\hline Intercept 2 & 0.318 & $(0.446)$ & -0.487 & $(0.455)$ \\
\hline Intercept 3 & $1.545 * * *$ & $(0.454)$ & $0.858 * *$ & $(0.453)$ \\
\hline Intercept 4 & $3.684 * * *$ & $(0.521)$ & $2.480 * * *$ & $(0.487)$ \\
\hline Country-level intercept & 0.000 & $(0.000)$ & 0.049 & $(0.182)$ \\
\hline Log-likelihood & -425.445 & & -419.198 & \\
\hline Wald Chi2 (10) & 34 & & 20 & \\
\hline Prob $>$ Chi 2 & 0.000 & & 0.029 & \\
\hline$N$ & 298 & & 299 & \\
\hline
\end{tabular}

Coefficients, standard errors (in parentheses), and significance are presented, whereby: ${ }^{*} P<0.1$; $* * P<0.05 ; * * * P<0.01$

Robustness check II. Seemingly unrelated regression analysis

\begin{tabular}{|c|c|c|c|c|}
\hline & \multicolumn{2}{|c|}{ Amplification } & \multicolumn{2}{|l|}{ Persuasion } \\
\hline & Coefficient & S.E. & Coefficient & S.E. \\
\hline \multicolumn{5}{|l|}{ Explanatory variables } \\
\hline Salience of issue & $0.317 * *$ & $(0.131)$ & $0.262 * *$ & $(0.127)$ \\
\hline Democratic accountability & $0.263 * *$ & $(0.109)$ & 0.078 & $(0.105)$ \\
\hline \multicolumn{5}{|l|}{ Function } \\
\hline Politician (ref.) & Ref. & & Ref. & \\
\hline Diplomat & $-0.418^{*}$ & $(0.254)$ & $-0.581 * *$ & $(0.245)$ \\
\hline Civil servant & -0.224 & $(0.222)$ & $-0.476^{* *}$ & $(0.215)$ \\
\hline Other & 0.089 & $(0.271)$ & -0.220 & $(0.262)$ \\
\hline \multicolumn{5}{|l|}{ Control variables } \\
\hline \multicolumn{5}{|l|}{ Level of development } \\
\hline High income (ref.) & Ref. & & Ref. & \\
\hline Medium high income & $0.489 * * *$ & $(0.204)$ & 0.322 & $(0.197)$ \\
\hline Medium low income & $0.571 * *$ & $(0.263)$ & 0.311 & $(0.254)$ \\
\hline Low income & $0.995^{* *}$ & $(0.271)$ & $0.504 *$ & $(0.262)$ \\
\hline \multicolumn{5}{|l|}{ Initiate contact } \\
\hline Evenly (ref.) & Ref. & & Ref. & \\
\hline Advocacy group & $-0.382 * * *$ & $(0.137)$ & -0.124 & $(0.132)$ \\
\hline Policymaker & 0.174 & $(0.193)$ & 0.310 & $(0.186)^{*}$ \\
\hline \multicolumn{5}{|l|}{ Diagnostics } \\
\hline Intercept & $2.419 * * *$ & $(0.258)$ & $-2.871 * * *$ & $(0.249)$ \\
\hline R-sq & 0.105 & & 0.074 & \\
\hline
\end{tabular}




\begin{tabular}{lllllll}
\hline & Amplification & & & Persuasion & \\
\cline { 2 - 3 } \cline { 5 - 6 } & Coefficient & S.E. & & Coefficient & S.E. \\
\hline Chi2 & 34.94 & & 23.76 & \\
Prob $>$ Chi2 & 0.000 & & & 0.008 & \\
$N$ & 297 & & 297 & \\
\hline
\end{tabular}

Coefficients, standard errors (in parentheses), and significance are presented, whereby: ${ }^{*} P<0.1$;

$* * P<0.05 ; * * * P<0.01$

\section{References}

Ainsworth, S. 1993. Regulating Lobbyists and Interest Groups Influence. Journal of Politics 55(1): 41-56.

Ainsworth, S. 1997. The Role of Legislators in the Determination of Interest Group Influence. Legislative Studies Quarterly 22(4): 517-533.

Austen-Smith, D., and J.R. Wright. 1994. Counteractive Lobbying. American Journal of Political Science 38(1): 25-44.

Austen-Smith, D., and J.R. Wright. 1996. Theory and Evidence for Counteractive Lobbying. American Journal of Political Science 40(2): 543-564.

Bauer, R.A., Pool I. de Sola, and L.A. Dexter. 1963. American Business and Public Policy: The Politics of Foreign Trade. New York: Atherton.

Baumgartner, F.R., and B.L. Leech. 1998. Basis Interests: The Importance of Groups in Politics and Political Science. Princeton: Princeton University Press.

Baumgartner, F.R., J.M. Berry, M. Hojnacki, D.C. Kimball, and B.L. Leech. 2009. Lobbying and Policy Change: Who Wins, Who Loses, and Why. Chicago: The University of Chicago Press.

Beckfield, J. 2003. Inequality in the World Polity: The Structure of International Organization. American Sociological Review 68(3): 401-424.

Bernauer, T., T. Boehmelt, and V. Koubi. 2013. Is There a Democracy-Civil Society Paradox in Global Environmental Governance? Global Environmental Politics 13(1): 88.

Bernhagen, P., and T. Bräuninger. 2005. Structural Power and Public Policy: A Signaling Model of Business Lobbying in Democratic Capitalism. Political Studies 53(1): 43-64.

Beyers, J., and C. Braun. 2014. Ties that Count: Explaining Interest Group Access to Policymakers. Journal of Public Policy 34(1): 93-121.

Beyers, J., and M. Hanegraaff. 2017. Balancing Friends and Foes: Explaining Advocacy Styles at Global Diplomatic Conferences. Review of International Organizations 12(3): 461-484.

Beyers, J., and B. Kerremans. 2004. Bureaucrats, Politicians, and Societal Interests: How is European Policy Making Politicized? Comparative Political Studies 37(10): 1119-1150.

Binderkrantz, A.S., P.M. Christiansen, and H.H. Pedersen. 2014. A Privileged Position? The Influence of Business Interests in Government Consultations. Journal of Public Administration Research and Theory 24(4): 879-896.

Bloodgood, E., and J. Tremblay-Boire. 2017. Does Government Funding Depoliticize Non-governmental Organizations? Examining Evidence from Europe. European Political Science Review 9(3): 401-424.

Bouwen, P. 2002. Corporate Lobbying in the European Union: The Logic of Access. Journal of European Public Policy 9(3): 365-390.

Bunea, A., and F.R. Baumgartner. 2014. The State of the Discipline: Authorship, Research Designs, and Citation Patterns in Studies of EU Interest Groups and Lobbying. Journal of European Public Policy 21(10): 1412-1434.

Chalmers, A.W. 2011. Interests, Influence and Information: Comparing the Influence of Interest Groups in the European Union. Journal of European Integration 33(4): 471-486.

Chalmers, A.W. 2013a. Trading Information for Access: Informational Lobbying Strategies and Interest Group Access to the European Union. Journal of European Public Policy 20(1): 39-58. 
Chalmers, A.W. 2013b. With a Lot of Help from Their Friends: Explaining the Social Logic of Informational Lobbying in the European Union. European Union Politics 14(4): 475-496.

Cooley, A., and J. Ron. 2002. The NGO Scramble: Organizational Insecurity and the Political Economy of Transnational Action. International Security 27(1): 5-39.

Corell, E., and M.M. Betsill. 2001. A Comparative Look at NGO Influence in International Environmental Negotiations: Desertification and Climate Change. Global Environmental Politics 1(4): 86-107.

Cowles, M.G. 2003. Non-state Actors and False Dichotomies: Reviewing IR/IPE Approaches to European integration. Journal of European Public Policy 10(1): 102-120.

Crombez, C. 2002. Information, Lobbying and the Legislative Process in the European Union. European Union Politics 3(1): 7-32.

Dalton, R.J., S. Recchia, and R. Rohrschneider. 2003. The Environmental Movement and the Modes of Political Action. Comparative Political Studies 36(7): 743-771.

Dellmuth, L.M., and E.A. Bloodgood. 2018. Advocacy Groups in Global Governance : Global and Domestic Opportunity Structures. Interest Groups \& Advocacy (forthcoming): 1-23.

Dellmuth, L.M., and J. Tallberg. 2017. Advocacy Strategies in Global Governance: Inside versus Outside Lobbying. Political Studies 65(3): 705-723.

Finnemore, M., and K. Sikkink. 2007. International Norm Dynamics and Political Change. International Organization 52(4): 887-917.

Green, J.F., and G. Auld. 2017. Unbundling the Regime Complex: The Effects of Private Authority. Transnational Environmental Law 6(2): 259-284.

Gulbrandsen, L.H., and S. Andresen. 2004. NGO Influence in the Implementation of the Kyoto Protocol: Compliance, Flexibility Mechanisms, and Sinks. Global Environmental Politics 4(4): 54-75.

Gullberg, A.T. 2008. Lobbying Friends and Foes in Climate Policy: The Case of Business and Environmental Interest Groups in the European Union. Energy Policy 36(8): 2964-2972.

Hadden, J. 2015. Networks in Contention: The Divisive Politics of Climate Change. Cambridge: Cambridge University Press.

Hall, P.A. 2006. Systematic Process Analysis: when and how to use it. European Management Review 3(1): 24-31.

Hall, R.L., and A.V. Deardorff. 2006. Lobbying as Legislative Subsidy. The American Political Science Review 100(1): 69-84.

Hanegraaff, M., J. Beyers, and I. De Bruycker. 2016. Balancing Inside and Outside Lobbying: The Political Strategies of Lobbyists at Global Diplomatic Conferences. European Journal of Political Research 55(3): 568-588.

Hansen, J.M. 1991. Gaining Access: Congress and the Farm Lobby, 1919-1981. Chicago: Chicago University Press.

Heaney, M.T. 2006. Brokering Health Policy: Coalitions, Parties, and Interest Group Influence. Journal of Health Politics, Policy and Law 31(5): 887-944.

Heaney, M.T., and P. Leifeld. 2018. Contributions by Interest Groups to Lobbying Coalitions. Journal of Politics 80(2): 494-509.

Heaney, M.T., and F. Rojas. 2015. Party in the Street: The Antiwar Movement and the Democratic Party after 9/11. Cambridge: Cambridge University Press.

Heylen, F., and E. Willems. 2018. Writing Blank Checks? How Government Funding Affects Interest Organisations' Advocacy Behaviour in a Multi-Layered Context. Journal of European Public Policy 2018: 1-20.

Holyoke, T.T. 2009. Interest Group Competition and Coalition Formation. American Journal of Political Science 53(2): 360-375.

Holyoke, T.T. 2011. Competitive Interests: Competition and Compromise in American Interest Group Politics. Washington, D.C.: Georgetown University Press.

Jacobs, D. 1974. Dependency and Vulnerability: an exchange approach to the control of organizations. Administrative Science Quarterly 19(1): 45-59.

Jones, B.D., and F.R. Baumgartner. 2005. The Politics of Attention: How government prioritizes problems. Chicago: Chicago University Press.

Kitschelt, H.P. 1986. Political Opportunity Structures and Political Protest: Anti-Nuclear Movements in Four Democracies. British Journal of Political Science 16(1): 57-85.

Klüver, H. 2011. The Contextual Nature of Lobbying: Explaining Lobbying Success in the European Union. European Union Politics 12(4): 483-506. 
Klüver, H. 2012. Informational Lobbying in the European Union: The Effect of Organisational Characteristics. West European Politics 35(3): 491-510.

Klüver, H., C. Braun, and J. Beyers. 2015. Legislative Lobbying in Context: Towards a Conceptual Framework of Interest Group Lobbying in the European Union. Journal of European Public Policy 22(4): 447-461.

Kollman, K. 1997. Inviting Friends to Lobby: Interest Groups, Ideological Bias, and Congressional Committees. American Journal of Political Science 41(2): 519-544.

Kollman, K. 1998. Outside Lobbying: Public Opinion and Interest Group Strategies. Princeton: Princeton University Press.

Kriesi, H. 1995. The Political Opportunity Structure of New Social Movements: Its Impact on Their Mobilization. In The Politics of Social Protest. Comparative Perspectives on States and Social Movements, ed. J.C. Jenkins and B. Klandermans, 167-198. London: UCL Press.

Lee, T. 2010. The Rise of International Nongovernmental Organizations: A Top-Down or Bottom-Up Explanation? VOLUNTAS: International Journal of Voluntary and Nonprofit Organizations 21(3): 393-416.

Levine, S., and P.E. White. 1961. Exchange as a Conceptual Framework for the Study of Interorganizational Relationships. Administrative Science Quarterly 5(4): 583-601.

Lohmann, S. 1998. An Information Rationale for the Power of Special Interests. The American Political Science Review 92(4): 809-827.

Lowery D. 2007. Why Do Organized Interests Lobby? A Multi-goal, Multi-context Theory of Lobbying. Polity 39(1): 29-54.

Lucas, K. 2019. Behind Success Stories: Goal Attainment in Global Trade and Climate Negotiations. Interest Groups \& Advocacy 8(1): 44-67.

Mahoney, C. 2004. The Power of Institutions: State and Interest Group Activity in the European Union. European Union Politics 5(4): 441-466.

Mahoney, C. 2007. Lobbying Success in the United States and the European Union. Journal of Public Policy 27(1): 35-56.

Marshall, D. 2010. Who to Lobby and When: Institutional Determinants of Interest Group Strategies in European Parliament Committees. European Union Politics 11(4): 553-575.

Matthews, D.R. 1960. U.S. Senators and Their World. Chapel Hill: University of North Carolina Press.

Molenaers, N., S. Dewachter, and S. Dellepiane. 2011. Moving into the New Aid Approach, Dilemmas for NGOs: The Belgian Case. Public Administration and Development 31(3): 188-204.

Neumayr, M., U. Schneider, and M. Meyer. 2015. Public Funding and Its Impact on Nonprofit Advocacy. Nonprofit and Voluntary Sector Quarterly 44(2): 297-318.

Persson, T., and K. Edholm. 2018. Assessing the Effects of European Union Funding of Civil Society Organizations: Money for Nothing? Journal of Common Market Studies 56(3): 559-575.

Pfeffer, J., and G.R. Salancik. 1978. The External Control of Organizations: A Resource Dependence Perspective. New York: Harper \& Row.

Potters, J., and F. van Winden. 1992. Lobbying and Asymmetric Information. Public Choice 74(3): 269-292.

Prakash, A., and M. Potoski. 2014. Global Private Regimes, Domestic Public Law: ISO 14001 and Pollution Reduction. Comparative Political Studies 47(3): 369-394.

Raustiala, K. 1997. States, NGOs, and International Environmental Institutions. International Studies Quarterly 41(4): 719-740.

Risse-Kappen, T. 1995. Bringing Transnational Relations Back In. Non-State Actors, Domestic Structures and International Institutions. Cambridge: Cambridge University Press.

Risse, T., S.C. Ropp, and K. Sikkink. 2013. The Persistent Power of Human Rights. Cambridge: Cambridge University Press.

Salisbury, R.H. 1969. An Exchange Theory of Interest Groups. Midwest Journal of Political Science 13(1): 1-32.

Schattschneider, E.E. 1960. The Semi-Sovereign People: A Realist's View of Democracy in America. New York: Holt, Rinehart and Winston.

Skjelsbaek, K. 1971. The Growth of International Nongovernmental Organization in the Twentieth Century. International Organization 25(3): 420-442.

Smith, J., and D. Wiest. 2005. The Uneven Geography of Global Civil Society: National and Global Influences on Transnational Association. Social Forces 84(2): 621-651.

Steffek, J. 2013. Explaining Cooperation Between IGOs and NGOs-Push Factors, Pull Factors, and the Policy Cycle. Review of International Studies 39(4): 993-1013. 
Stroup, S.S., and W.H. Wong. 2017. The Authority Trap-Strategic Choices of International NGOs. Ithaca: Cornell University Press.

Tallberg, J., T. Sommerer, T. Squatrito, and C. Jönsson. 2014. Explaining the Transnational Design of International Organizations. International Organization 68(4): 741-774.

Tallberg, J., L.M. Dellmuth, H. Agné, and A. Duit. 2018. NGO Influence in International Organizations: Information, Access and Exchange. British Journal of Political Science 48(1): 213-238.

Verschuere, B., and J. De Corte. 2014. The Impact of Public Resource Dependence on the Autonomy of NPOs in Their Strategic Decision Making. Nonprofit and Voluntary Sector Quarterly 43(2): 293-313.

Wright, J.R. 1996. Interest Groups \& Congress: Lobbying, Contributions, and Influence. Boston: Allyn and Bacon.

Publisher's Note Springer Nature remains neutral with regard to jurisdictional claims in published maps and institutional affiliations. 